\title{
PENERAPAN METODE REGRESI LINIER SEDERHANA UNTUK PREDIKSI PERSEDIAAN OBAT JENIS TABLET
}

\author{
Harsiti $^{1}$, Zaenal Muttaqin ${ }^{2}$, Ela Srihartini ${ }^{3}$ \\ ${ }^{1,2,3}$ Jurusan Sistem Informasi Fakultas Teknologi Informasi Universitas Serang Raya \\ Jln. Raya Cilegon Serang - Drangong Kota Serang \\ ${ }^{1}$ harsiti.unsera@gmail.com \\ 2d.zaey.vu@gmail.com \\ Elasri405@gmail.com
}

\begin{abstract}
Abstrak
Klinik Teluk Banten merupakan salah satu klinik yang berlokasi di Jalan Kampung Margagiri Kecamatan Puloampel Kabupaten Serang Provinsi Banten, beroperasi baru Sembilan bulan lamanya. Fasilitas yang tersedia salah satunya adalah poli pelayanan rawat jalan dan instalasi farmasi yang mengelola dan mengatur persedian obat. Tujuan dari penelitian ini adalah membuat prediksi terhadap pengelolaan persediaan obat. Pengelolaan persediaan obat pada klinik ini dilakukan setiap satu minggu sekali dengan pencatatan manual. Transaski penjualan obat pun dicatat dalam pembukuan biasa yaitu dicatat dalam buku besar, sehingga proses kontrol terhadap persedian obat belum dapat dilakukan dengan baik, tidak dapat dilakukan proses prediksi terhadap persediaan obat yang harus dibeli untuk periode berikutnya. Hal ini disebabkan karena catatan transaski penjualan yang tersedia hanya digunakan sebagai catatan dan arsip saja dan belum digunakan sebagai data yang dapat mendukung proses prediksi untuk menentukan obat yang harus disediakan untuk periode minggu selanjutnya. Permasalahan ini dapat diatasi dengan mengimplementasikan metode regresi linier sederhana yang dapat digunakan sebagai salah satu pendekatan untuk menghasilkan informasi berupa hasil prediksi untuk persediaan obat dalam proses penjualan obat jenis tablet. Berdasarkan perhitungan dengan menggunakan metode regresi linier diperolah akurasi sebesar 98, 505\% yang artinya metode ini dapat diimplementasikan dalam membuat prediksi stok obat jenis tablet (ibu profen) pada Klinik Teluk.
\end{abstract}

Kata kunci: Persediaan Obat, Prediksi, Metode Regresi Linier Sederhana, Akurasi

\section{PENDAhUluan}

Aspek terpenting dalam kefarmasian adalah melakukan pengendalian persediaan dengan mengoptimalkan penyediaan obat termasuk perencanaan, pengadaan, penyimpanan, pendistribusian serta pemilihan dan pengendaliannya [1]. Persediaan (Inventory) obat baik di Apotik baik rumah sakit ataupun klinik pengobatan masyarakat merupakan salah satu bentuk investasi yang membutuhkan biaya yang tidak sedikit. Oleh karenanya diperlukan proses pengelolaan yang baik terhadap persediaan obat yang berhubungan dengan pelayanan rumah sakit atau klinik terhadap pasien dan ketersediaan obat yang sering tidak dapat diprediksi.

Persediaan obat perlu dikelola dengan baik karena berhubungan dengan stok obat yang tersedia di rumah sakit atau klinik terhadap pemenuhan kebutuhan pasien terhadap jenis obat tertentu. Pengelolaan persedian obat dapat dilakukan guna menghindari terjadinya harga obat yang sewaktu-waktu bisa meningkat, memenuhi kebutuhan pasien yang tidak dapat diprediksi dan mendapatkan keuntungan berupa pemotongan harga (dikson) dari pemasok (supplyer) jika pembelian obat dilakukan dalam jumlah tertentu [2].

Klinik Teluk Banten adalah klinik yang baru beroperasi selama sembilan bulan dalam pengobatan umum (rawat jalan), klinik ini berada di Jalan Kampung Margasari Desa Margasari Kecamatan Puloampel Kabupaten Serang Banten. Di Klinik tersebut terdapat Instalasi Farmasi yang bertugas mengelola persedian obat berbagai jenis. Beberapa jenis obat yang dikelola oleh klinik ini seperti tablet, sirup, kapsul, puyer, pil dan lain sebagainya. Jenis obat yang banyak digunakan oleh klinik ini adalah obat jenis tablet. Obat jenis tablet ini merupakan jenis obat yang banyak terjual setiap minggunya. 
Hal ini dibuktikan dengan adanya catatan transaksi penjualan obat yang dicatat dalam buku besar.

Catatan transaksi ini digunakan hanya sebatas sebagai arsip untuk setiap transaksi yang terjadi setiap harinya. Namun belum dimanfaat untuk membuat prediksi untuk persediaan obat untuk periode selanjutnya. Diperlukannya proses prediksi ini dimaksudkan agar persediaan obat tidak sampai kosong sehingga tidak mengecewakan pasien jika ingin membeli obat. Sehingga dapat dilakukan control terhadap ketersediaan stok obat yang dikelola oleh Instalasi Farmasi pada klinik tersebut. Klinik dapat tetap memberikan pelayanan terhadap kebutuhan obat pasien yang berkunjung dan dapat melakukan pengendalian persediaan dengan baik.

Metode Regresi Linier Sederhana merupakan suatu metode yang digunakan untuk melihat hubungan antar satu variabel independent (bebas) dan mempunyai hubungan garis lurus dengan variabel dependennya (terikat). Sebuah variabel hasil observasi yang diperoleh sangat mungkin dipengaruhi oleh variabel lainnya, misalkan tinggi badan dan berat badan seseorang. Untuk suatu tinggi tertentu ada besaran berat badan yang mempengaruhi, demikian juga sebaliknya. Contoh lain misalnya produksi padi yang dipengaruhi oleh luas lahan yang ditanami, jenis pupuk yang dipakai, banyaknya pupuk yang dipakai dll [3].

Regresi linear sederhana atau sering disingkat dengan SLR (Simple Linier Regression) juga merupakan salah satu metode statistik yang dipergunakan dalam produksi untuk melakukan peramalan atau pun prediksi tentang karakteristik kualitas maupun kuntitas. Persamaan umum metode regresi linier sederhana dalam penelitian ini adalah:

$$
y=a+b x
$$

Keterangan:

$\mathrm{a}=$ Konstanta

$\mathrm{b}=$ Koefisien regresi

$\mathrm{Y}=$ Variabel dependen (variabel tak bebas)

$\mathrm{X}=$ Variabel independen (variabel bebas)

Menghitung konstanta (a):

$$
a=\frac{\left(\sum \mathrm{y}\right)\left(\sum \mathrm{x}^{2}\right)-\left(\sum \mathrm{x}\right)\left(\sum \mathrm{xy}\right)}{\mathrm{n}\left(\sum \mathrm{x}^{2}\right)-\left(\sum \mathrm{x}\right)^{2}}
$$

Menghitung koefisien (b):

$$
b=\frac{\mathrm{n}(\Sigma \mathrm{xy})-(\Sigma \mathrm{x})(\Sigma \mathrm{y})}{\mathrm{n}\left(\Sigma \mathrm{x}^{2}\right)-(\Sigma \mathrm{x})^{2}}
$$

\section{Perhitungan Error}

Metode untuk mengevaluasi metode peramalan menggunakan jumlah dari kesalahan-kesalahan yang absolut. Mean Absolute Deviation (MAD) mengukur ketepatan ramalan dengan merata-rata kesalahan dugaan (nilai absolut masing-masing kesalahan). MAD berguna ketika mengukur kesalahan ramalan dalam unit yang sama sebagai deret asli. MAD merupakan ukuran pertama kesalahan peralan keseluruhan untuk sebuah model. Rumus untuk menghitun MAD adalah sebagai berikut :

$$
M A D=\frac{\sum|Y t-F t|}{n}
$$

\section{Metodologi Penelitian}

Penelitian ini diawali dengan melakukan identitikasi permasalahan yang dihadapi pada Klinik Teluk Banten. Identifikasi dilakukan dengan cara mengamati dan melakukan observasi terhadap sistem yang sedang berjalan pada saat ini. Dilanjutkan dengan melakukan kajian pustka dan pengumpulan data. Pengumpulan data dilakukan dengan mengamati transaksi dan catatan transaksi yang terjadi tiap harinya pada Klinik Teluk Banten. Lebih jelasnya, tahapantahapan penelitian ditunjkkan pada Gambar 1 dibawah ini :

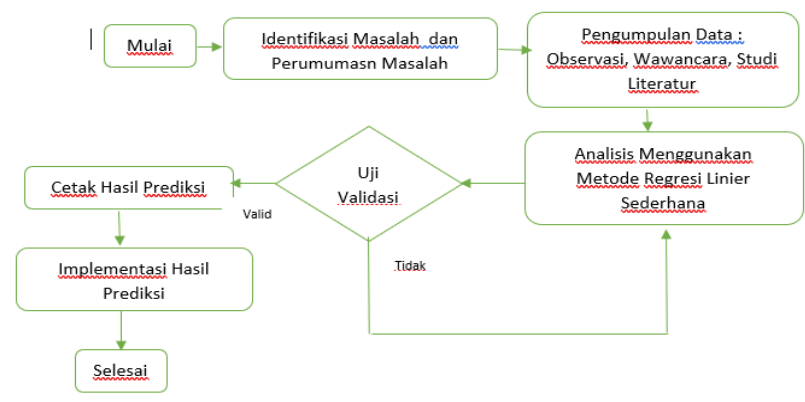

Gambar 1. Tahapan Penelitian

\section{HASIL DAN PEMBAHASAN}

\section{A. Analisis Sistem Yang Berjalan}

Pada sistem yang berjalan, proses pengelolaan persedian obat dilakukan dengan melakukan pencatatan transaksi secara manual yaitu dicatat dalam sebuah buku besar sehingga hal ini menyebabkan proses kontrol terhadap persediaan obat sulit dilakukan khususnya jenis obat tablet. Sering kali pasien kecewa karena obat yang akan dibeli atau diresepkan dokter tidak tersedia di Apotik.Sehingga sering terjadinya kekosongan stok obat, adapaun jalannya sistem pada saat ini ditunjukkan pada Gambar 2 di bawah ini : 


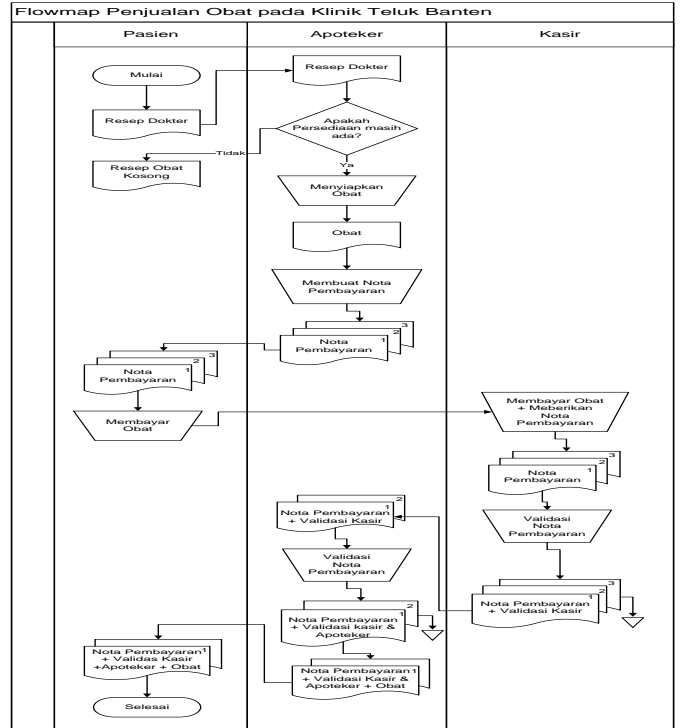

Gambar 2. Flowchart Penjualan Obat Pada Klinik Teluk Banten

\section{B. Hasil Pengumpulan Data}

Dalam penelitian ini berhasil dikumpulkan data transaksi penjualan obat jenis tablet (Ibu Profen) seperti yang ditunjukkan pada Tabel 1.

Tabel 1. Data Transaksi Penjualan Obat Periode Januari-Agustus 2020.

\begin{tabular}{|c|c|c|c|c|c|c|}
\hline \multicolumn{7}{|c|}{$\begin{array}{l}\text { DATA PENJUALAN OBAT JENIS TABLET (IBU PROFEN) } \\
\text { PER LEMPENG PADA KLINIK TELUK BANTEN } \\
\text { PERIODE JANUARI - AGUSTUS 2020 }\end{array}$} \\
\hline \multirow[b]{2}{*}{ TAHUN } & \multirow{2}{*}{ BULAN } & \multicolumn{4}{|c|}{ PERIODE (MINGGU) } & \multirow{2}{*}{ TOTAL } \\
\hline & & 1 & 2 & 3 & 4 & \\
\hline \multirow{8}{*}{2019} & JANUARI & 18 & 24 & 42 & 50 & 134 \\
\hline & FEBRUARI & 45 & 27 & 34 & 52 & 158 \\
\hline & MARET & 48 & 55 & 52 & 65 & 220 \\
\hline & APRIL & 77 & 82 & 95 & 103 & 357 \\
\hline & MEI & 110 & 114 & 107 & 126 & 457 \\
\hline & JUNI & 124 & 130 & 132 & 140 & 526 \\
\hline & JULI & 146 & 148 & 157 & 159 & 610 \\
\hline & AGUSTUS & 163 & 172 & 175 & 181 & 691 \\
\hline
\end{tabular}

Berdasarkan daftar kunjungan pasien ke klinik, terdapat 23.077 pasien yang berobat pada Klinik Teluk Banten selama periode Januari - Agustus 2019. Hal menunjukkan terdapat $\pm 14 \%$ pasien dari jumlah pasien keseluruhan yang membutuhkan obat jenis tablet ibu profen dengan jumlah obat ibu profen yang terjual selama periode Januari Agustus sebanyak 3.153 lempeng.

\section{Analisis Mengunakan Metode Regresi Linier Sederhana}

Langkah-langkah analisis menggunakan metode regresi linier sederhana sebagai berikut :

1. Menentukan tujuan dari melakukan analisis regregsi linier

Tujuan dari analisis ini adalah untuk membuat prediksi penjualan obat jenis tablet (ibuprofen) sehingga tidak terjadi keterlambatan dalam persediaan obat dan dapat meminimalisirkan adanya kerugian yang terjadi pada Klinik Teluk Banten.

2. Mengidentifikasi variable factor penyebab $(\mathrm{X})$ dan variable akibat (Y).

Variabel faktor penyebab (X) dalam kasus ini adalah jumlah periode/waktu sedangkan variabel akibat nya (Y) adalah jumlah obat jenis tablet.

3. Melakukan Pengumpulan Data

Pada kasus ini menggunakan data penjualan periode Januari - Agustus 2019 dapat dilihat pada tabel 3.2 untuk perhitungan data set menggunakan data penjualan periode Januari - Mei 2020.

4. Menghitung XY dan $\mathrm{X}^{2}$

Berdasarkan pada Tabel 1 yaitu data penjualan obat jenis ibu profen pada Klini Teluk Banten diperoleh hasil diperoleh hasil perhitungan $\mathrm{XY}$ dan $\mathrm{X}^{2}$ seperti pada Tabel 2 berikut :

Tabel 2. Perhitungan $X Y$ dan $X^{2}$

\begin{tabular}{|c|c|c|c|c|c|}
\hline TAHUN & BULAN & $\begin{array}{l}\text { PERTODE } \\
\text { AmNGGU } \\
(\mathbb{N}),\end{array}$ & $\underset{(M)}{\text { TABIET }}$ & $\mathbf{x Y}$ & $x 2$ \\
\hline \multirow{20}{*}{2010} & \multirow{4}{*}{ JANUARI } & 1 & 18 & 18 & 1 \\
\hline & & 2 & 24 & 48 & 4 \\
\hline & & 3 & 42 & 126 & 9 \\
\hline & & 4 & 50 & 200 & 16 \\
\hline & \multirow{3}{*}{ FEBRUARI } & 5 & 45 & 225 & 25 \\
\hline & & 6 & 27 & 162 & 36 \\
\hline & & $\frac{7}{8}$ & $\frac{34}{52}$ & $\frac{238}{416}$ & 49 \\
\hline & \multirow{4}{*}{ MAARET } & 9 & 48 & 432 & 81 \\
\hline & & 10 & 55 & 550 & 100 \\
\hline & & 11 & 52 & 572 & 121 \\
\hline & & 12 & 65 & 780 & 144 \\
\hline & \multirow{4}{*}{ APRII } & 13 & 77 & 1.001 & 169 \\
\hline & & 14 & 82 & 1.148 & 196 \\
\hline & & 15 & 95 & 1.425 & 225 \\
\hline & & 16 & 103 & 1.648 & 256 \\
\hline & \multirow{4}{*}{ MEI } & 17 & 110 & 1.870 & 289 \\
\hline & & 18 & 114 & 2.052 & 324 \\
\hline & & 19 & 107 & 2.033 & 361 \\
\hline & & 20 & 126 & 2.520 & 400 \\
\hline & & $=210$ & $\Sigma=1.326$ & $\Sigma=1.7464$ & $\mathbf{I}=2.870$ \\
\hline
\end{tabular}

5. Mencari Nilai Konstanta

Nilai konstanta diperoleh dari Tabel 2 yaitu table Perhitungan $\mathrm{XY}$ dan $\mathrm{X}^{2}$ dihitung dengan menggunakan persamaan (2), maka diperoleh hasil sebagai berikut ::

$$
\begin{aligned}
& a=\frac{(\Sigma \mathrm{y})\left(\sum \mathrm{x}^{2}\right)-(\Sigma \mathrm{x})\left(\sum \mathrm{xy}\right)}{\mathrm{n}\left(\Sigma \mathrm{x}^{2}\right)-(\Sigma \mathrm{x})^{2}} \\
& a=\frac{(1.326)(2.870)-(210)(17.464)}{20(2.870)-(210)^{2}} \\
& a=\frac{(3.805 .620-3.667 .440)}{57.400-44.100} \\
& a=\frac{138.180}{13.300} \\
& \boldsymbol{a}=\mathbf{1 0 , 3 8 9}
\end{aligned}
$$

Maka nilai konstanta nya adalah $\mathbf{a}=\mathbf{1 0 , 3 8 9}$

6. Mencari Nilai Koefisien 
Mencari nilai koefisien diperolah dengan menggunakan rumuas pada persamaan (3). Diperoleh hasil sebagai berikut :

$$
\begin{aligned}
& \frac{\mathrm{n}(\Sigma \mathrm{xy})-(\Sigma \mathrm{x})(\Sigma \mathrm{y})}{\mathrm{n}\left(\Sigma \mathrm{x}^{2}\right)-(\Sigma \mathrm{x})^{2}} \\
& \text { Sehingga : } \\
& b=\frac{\mathrm{n}(\Sigma \mathrm{xy})-(\Sigma \mathrm{x})(\Sigma \mathrm{y})}{\mathrm{n}\left(\Sigma \mathrm{x}^{2}\right)-(\Sigma \mathrm{x})^{2}} \\
& b=\frac{20(17.464)-(210)(1.326)}{20(2.870)-(210)^{2}} \\
& b=\frac{349.280-278.460}{13.300} \\
& b=\frac{70.820}{13.300} \\
& \boldsymbol{b}=\mathbf{5 , 3 2 5} \\
& \text { Maka nilai koefisiennya adalah } \mathbf{b}=\mathbf{5 , 3 2 5}
\end{aligned}
$$

7. Menentukan Persamaan Regresi

Persamaan Regresi diperoleh menggunakan rumus persamaan (1), hasilnya sebagai berikut :

$$
\begin{aligned}
& y=a+b x \\
& \text { Sehingga : } \\
& y=a+b x \\
& y=10,389+5,325 x \ldots \ldots \ldots \text { (5) }
\end{aligned}
$$

\begin{tabular}{|c|c|c|c|}
\hline Tahum & Bulan & Periode (X) & Prediksi \\
\hline \multirow{12}{*}{2020} & \multirow{4}{*}{ Juni. } & 21 & 122.214 \\
\hline & & 22 & 127.539 \\
\hline & & 23 & 132.864 \\
\hline & & 24 & 138.189 \\
\hline & \multirow{4}{*}{ Juli. } & 25 & 143.514 \\
\hline & & 26 & 148.839 \\
\hline & & 27 & 154.164 \\
\hline & & 28 & 159.489 \\
\hline & \multirow{4}{*}{ Agustus } & 29 & 164.814 \\
\hline & & 30 & 170.139 \\
\hline & & 31 & 175.464 \\
\hline & & 32 & 180.789 \\
\hline
\end{tabular}

8. Menghitung Prediksi

Setelah mendapatkan persamaan regresi yaitu persamaan (5) maka persamaan tersebut dilanjutkan untuk menghitung prediksi persediaan obat untuk minggu ke-21 sampai dengan 32. Diperoleh hasil seperti yang ditunjukkan pada Tabel 3 sebagai

\begin{tabular}{|c|c|c|c|c|c|c|c|}
\hline Tahun & Bulan & (t) & (Yt) & (Ft) & Yt-Ft & $\mid \mathbf{Y t}-\mathbf{F t}$ & MAD \\
\hline \multirow{12}{*}{2019} & \multirow{4}{*}{ Juni } & 21 & 124 & 122.214 & 1.786 & 1.786 & 0.1488 \\
\hline & & 22 & 130 & 127.539 & 2.461 & 2.461 & 0.2051 \\
\hline & & 23 & 132 & 132.864 & -0.864 & 0.864 & 0.072 \\
\hline & & 24 & 140 & 138.189 & 1.811 & 1.811 & 0.1509 \\
\hline & \multirow{4}{*}{ Juli } & 25 & 146 & 143.514 & 2.486 & 2.486 & 0.2072 \\
\hline & & 26 & 148 & 148.839 & -0.839 & 0.839 & 0.0699 \\
\hline & & 27 & 157 & 154.164 & 2.836 & 2.836 & 0.2363 \\
\hline & & 28 & 159 & 159.489 & -0.489 & 0.489 & 0.0408 \\
\hline & \multirow{4}{*}{ Agustus } & 29 & 163 & 164.814 & -1.814 & 1.814 & 0.1512 \\
\hline & & 30 & 172 & 170.139 & 1.861 & 1.861 & 0.1551 \\
\hline & & 31 & 175 & 175.464 & -0.464 & 0.464 & 0.0387 \\
\hline & & 32 & 181 & 180.789 & 0.211 & 0.211 & 0.0176 \\
\hline \multicolumn{2}{|c|}{ Total } & 318 & 1.827 & 1818,018 & 8,982 & 17,922 & 1,4935 \\
\hline
\end{tabular}
berikut:

Tabel 3. Tabel Hasil Prediksi

9. Perhitungan Error

Perhitungan error ini menggunakan persamaan (4) nilai ini dihitung dengan mengambil jumlah nilai absolute kesalahan peramalan individual (deviasi) dan membaginya dengan jumlah periode data. Sebagaimana perhitungan error bisa dilihat pada Tabel 4 sebagai berikut :
Tabel 4. Perhitungan Error

Berdasarkan nilai MAD di atas maka dapat disimpulkan bahwa hasil prediksi dengan menggunakan metode regresi linier sederhana dengan tingkat kesalahan 1,4953\%. Dari hasil nilai error tersebut maka dapat dihitung keakurasian prediksinya dengan menggunakan rumus di bawah ini :

$$
\begin{aligned}
& \text { Akurasi }=100 \%-\text { Error } \\
& \text { Akurasi }=100 \%-1,4953 \% \\
& \text { Akurasi }=\mathbf{9 8}, \mathbf{5 0 5} \%
\end{aligned}
$$

Nilai akurasi yang diperoleh sebesar $\mathbf{9 8 , 5 0 5 \%}$ sehingga hasil prediksi yang diperoleh disimpulkan akurat dan metode regresi linier sederhana dapat diimplementasikan pada Klinik Teluk Banten untuk memprediksi persedian obat jenis tablet (ibu profen).

\section{KESIMPULAN}

Berdasarkan hasil analasis data transaksi penjualan obat di Klinik Teluk Banten menggunakan metode regresi linier sederhana diperoleh hasil akurasi sebesar 98,505\%. Maka dapat disimpulkan bahwa metode regresi linier sederhana dapat menentukan hasil prediksi yang akurat untuk memprediksi stok obat dalam pengelolaan persediaan obat jenis tablet (ibu profen) dapat diterapkan pada Klinik Teluk Banten.

\section{SARAN}

Untuk memperoleh hasil yang lebih akurat, maka disarankan untuk penelitian selanjutnya perlu dilakukan perbandingan dengan menggunakan metode prediksi yang lainnya atau perhitungan di atas dapat dilakukan dengan menggunakan aplikasi seperti SPSS versi 25. Disarankan juga untuk mengembangkan perangkat lunak untuk mempermudah pihak Farmasi melakukan prediksi untuk jenis obat yang lainnya. 


\section{REFERENSI}

[1] Ayuni, Ghebyla Najla dkk, 2019, Penerapan Metode Regresi Linear Untuk Prediksi Penjualan Properti pada PT XYZ, Jurnal Telematika Vol. 14, No. 2 Institute Teknologi Harapan Bangsa, Bandung, 2019, p-ISSN: 1858-2516 e-ISSN: 2579-377.

[2] Henky Saputra, Medianto. Pengelolaan Persediaan Obat available https://supplychainindonesia.com/pengelolaanpersediaan-obat-di-apotek/, tgl akses 05 Januari 2022. 2020.

[3] Statma, Contoh Soal Dan Pembahasan Regresi Linier Sederhana, available at https://www.statmat.net/regresilinier-sederhana/, tgl akses 05 Januari 2020. 2020.

[4] Baihaqi, dkk. Regresi Linier Sederhana Untuk Memprediksi Kunjungan Pasien Di Rumah Sakit Berdasarkan Jenis Layanan Dan Umur Pasien,, Jurnal Teknik Industri, Mesin, Elektronika dan Ilmu Komputer (SIMETRIS), Vol. 10 No. 2 November 2019, P-ISSN: 2252-4983, E-ISSN: 2549-3108. 2019.

[5] Hijria, Astria, dkk. Implementasi Metode Regresi Linier Sederhana Pada Penyajian Hasil Prediksi Pemakaian Air Bersih Pdam Way Rilau Kota Bandar Lampung Dengan Sistem Informasi Geofrafis, Jurnal Informatika Mulawarman, Vol. 11 No. 2, September 2016, ISSN 1858-4853. 2016. 